\title{
Telaah Konsepsi Negara Hukum dan Demokrasi dalam Pembentukan Blue Constitution Di Indonesia
}

\author{
Fathan Ali Mubiina \\ Program Magister Ilmu Hukum Universitas Indonesia, Jakarta, Indonesia \\ E-mail: fathanalim03@gmail.com
}

\begin{abstract}
The supporting idea of this topics relates to the term of exclusive economic zone which is defined as a territorial sea outside, coastal states that have sovereignty over all natural resources in them and have the right to the application of Coastal state jurisdiction. This zone is located at 200 miles from the base of the territorial sea. Indonesia requires the Blue Constitution or maritime constitution as a constitutional basis for the use of maritime territory in Indonesia. This is what is said to be horizontally integrated territory. There is also the condition of a country's territorial territory separated from other countries' territorial territories. The essence of the state is to control a territory and be recognized internationally. There is existing country if it occupies an area which is its right to the interests of social and geographical unity. The sea area of a country such as Indonesia contained in the provisions of the 1945 Constitution is referred as the blue constitution inside.
\end{abstract}

Keywords: Blue Constitution; State; Maritime.

\section{A. PENDAHULUAN}

Reformasi menjadi momentum perubahan bangsa Indonesia untuk menata kehidupan bernegara yang lebih baik. Kehidupan bernegara terikat pada pembentukan struktur dari konstitusi sampai dengan penyelenggaraan negara. Struktur pun merupakan kiasan antara norma yang lebih tinggi dengan norma yang lebih rendah. Reformasi di Indonesia sebagai titik dimana keterbukaan, kebebasan, dan perlindungan hak diatur secara eksplisit dtuangkan dalam amandemen Undang-Undang Dasar 1945 (UUD 1945). Masa ini pun menjadi ajang untuk memperbaiki sistem dan kelembagaan secara konsekuen. Salah satu produk dari reformasi ialah amandemen UUD 1945 hingga ke empat.

Para stakeholder pada saat masa reformasi ini mulai menyempurnakan prinsip kedaulatan rakyat, dengan menafsirkan dari berbagai pendekatan termasuk pendekatan historis mengenai ketentuan kedaulatan rakyat. Penafsiran kedaulatan rakyat sebagai penjelmaan prinsip demokrasi memang sudah terjadi setiap masa kepemimpinan di Indonesia. Dikarenakan dasar konstitusi Indonesia perihal kedaulatan rakyat sudah diatur secara jelas di dalam pembukaan (preambule) dan Pasal 1 butir 2 Undang-Undang Dasar 
1945. Dari sebelum amandemen hingga pasca amandemen tidak ada perubahan dasar kedaulatan Indonesia. Yang mengalami perubahan itu ialah konsep pengamalannya atau pelaksana-annya yang sebelum amandemen dilakukan sepenuhnya oleh Majelis Permusyawaratan Rakyat, kemudian di amandemen ketiga dengan dilaksanakan menurut Undang-Undang Dasar.

Setiap kepemimpinan memaknai kedaulatan rakyat dengan interpretasinya masingmasing, dari yang bersifat kolektivitas hingga individualitas. Akan tetapi, pasca amandemen dibuat pemaknaan kedaulatan rakyat yang dikaitkan pada Pancasila, yang disebut demokrasi Pancasila. Maka dari itu pada makalah ini akan dijelaskan politik hukum perumusan kedaulatan rakyat yang digagas oleh para founding fathers Indonesia hingga masa reformasi. Perlu dicermati bahwa prinsip demokrasi yang menyatakan bahwa sumber dari suatu kekuasaan ialah rakyat. Penjabaran dari konsep dasar tersebut dicantumkan dalam Pembukaan Alinea Keempat UUD 1945 dan Pasal 1 ayat 2 UUD 1945. Prinsip yang dibentuk ialah prinsip kedaulatan rakyat dan prinsip negara hukum (rechtsstaat). Akibat dari penerapan kedua prinsip tersebut Indonesia menganut sistem negara hukum yang demokratis. Segala ketentuan peraturan perundang-undangan yang dibentuk berdasarkan UUD 1945 harus melalui mekanisme yang demokratis.

Berkaitan dengan pemaknaan negara hukum dan demokrasi, penulis mengaitkannya pada kondisi stabilitas kedaulatan negara yang terjadi pada abad 21 ini. Kondisi sosial saat ini yaitu belum adanya pengaturan maritim di konstitusi kita. Hingga saat tugas ini dibuat, wilayah laut kita masih mendasari pada keberadaan hukum laut internasional, sedangkan menurut Jimly Asshiddiqie dalam sambutannya di Dies Natalis Fakultas Hukum UI 2017, Indonesia memerlukan Blue Constitution atau konstitusi maritim sebagai dasar konstitusi pemanfaatan wilayah laut di Indonesia. Maka dari itu, melihat negara hukum dan demokrasi isu kemaritiman di Indonesia

Dari pemaparan diatas, akan dibahas mengenai permasalahan tentang "Bagaimana konsepsi negara hukum dan demokrasi dalam isu kemaritiman di Indonesia, khususnya kedaulatan wilayah perairan di Indonesia".

\section{B. METODE PENELITIAN}

Jenis penelitian yang penulis gunakan adalah penelitian yuridis-normatif. Pada penelitian Yuridis Normatif itu sendiri adalah penelitian yang dilakukan berdasarkan bahan hukum utama dengan cara menelaah teori-teori, konsep-konsep, asas-asas hukum serta peraturan perundang undangan yang berhubungan dengan penelitian ini. Untuk itu diperlukan penelitian yang merupakan suatu rencana pokok dalam pengembangan ilmu pengetahuan. Menurut Soerjono Soekanto pendekatan yuridis normatif yaitu penelitian hukum yang dilakukan dengan cara meneliti bahan pustaka atau data sekunder sebagai bahan dasar untuk diteliti dengan cara mengadakan penelusuran terhadap peraturanperaturan dan literatur-literatur yang berkaitan dengan permasalahan yang diteliti. ${ }^{1}$

Tipologi penelitian ini ialah preskriptif. Dapat diartikan sebagai penelitian hukum yang bersifat mendasar dan bertujuan untuk memperoleh keterangan, informasi, dan data mengenai hal-hal yang belum diketahui. Penelitian hukum preskriptif tidak memerlukan hipotesis atau teori tertentu. Metode pengumpulan data sekunder yang digunakan adalah berasal dari buku maupun peraturan perunndang-undangan. Oleh karenanya Penelitian

1 Soekanto, Soerjono dan Mamudji, Sri. (2001). Penelitian Hukum Normatif (Suatu Tinjauan Singkat), Jakarta: Rajawali Pers, h. 13-14.

53 | S A S I Vol. $26 \mathrm{No.1}$, Januari-Maret 2020 
hukum preskriptif seringkali menjadi semacam studi kelayakan (feasibility study). ${ }^{2}$

Penelitian hukum normatif atau penelitian hukum doktrinal yang condong bersifat kualitatif berdasarkan data sekunder. ${ }^{3}$ Ciri-ciri data sekunder yakni data sekunder pada umumnya ada dalam keadaan siap (ready-made), bentuk dan isi data sekunder telah dibentuk dan diisi oleh peneliti-peneliti terdahulu, dan data sekunder dapat diperoleh tanpa terikat atau dibatasi oleh waktu dan tempat. ${ }^{4}$ Dalam penelitian hukum normatif, dikenal tiga jenis metode pengumpulan data sekunder, namun pada penelitian ini menggunakan studi kepustakaan yaitu Studi kepustakaaan, yaitu pengkajian informasi tertulis mengenai hukum yang berasal dari berbagai sumber dan dipublikasikan secara luas serta dibutuhkan dalam penelitian hukum normatif. Berbagai sumber tersebut adalah:

1) Peraturan perundang-undangan.

2) Buku ilmu hukum.

3) Artikel yang termuat dalam jurnal hukum.

4) Pengamat hukum, produk hukumnya disebut tinjauan hukum yang termuat dalam media cetak.

Informasi tertulis yang diperoleh dari sumber-sumber di atas lazim disebut bahan hukum (law material). Bahan hukum tersebut yang digunakan dalam penelitian ini menjadi dua golongan, yaitu: ${ }^{5}$

a) Bahan hukum primer (primary law material), yaitu bahan hukum yang mempunyai kekuatan mengikat secara umum (perundang- undangan) atau mempunyai kekuatan mengikat bagi pihak-pihak berkepentingan (kontrak, konvensi, dokumen hukum, dan putusan hakim).

b) Bahan hukum sekunder (secondary law material), yaitu bahan hukum yang memberi penjelasan terhadap bahan hukum primer (buku ilmu hukum, jurnal hukum, laporan hukum, dan media cetak, atau elektronik).

Kegiatan menghimpun data sekunder yang terdiri dari bahan hukum primer dan bahan hukum sekunder secara sistematis. Penulis mengelaborasi atas data yang sudah dihimpun dalam penglompokkan secara sistematis menurut klasifikasi data dan urutan masalah karena data tersebut merupakan Data Kualitatif.

\section{PEMBAHASAN}

\section{Blue Constitution dalam Negara Hukum Indonesia}

Para founding fathers menentukan paradigm bernegara dengan menggabung-kan konsep dari barat dengan menggabung-kannya dengan ciri khas yang dimiliki oleh Indonesia. Konsep bernegara dipadupadan-kan ke dalam lima unsur dalam Pancasila yaitu, ketuhanan (theism), kemanusiaan (humanism), kebangsaan (nasionalism), kerakyatan (democracy), dan keadilan sosial (socialism). ${ }^{6}$ Unsur-unsur Pancasila terdiri dari nilai-nilai yang berifat umum atau universal dalam kehidupan bernegara, di sisi lain para bapak bangsa hendak menggabungkan sisi tradisionalisme di dalam Pancasila. Dalam perumusan tadi memang adanya dialektika yang hampir dead lock mengenai konsepsi dasar ideology negara. Antara Soepomo, Mr. A.A. Maramis, Soekarno dan

\footnotetext{
2 Muhammad, Abdulkadir.(2004). Hukum dan Penelitian Hukum, Bandung: Citra Aditya Bakti, h. 49.

3 Soekanto, Soerjono dan Mamudji, Sri. Penelitian Hukum Normatif, h. 24.

4 Ibid.

5 Abdulkadir Muhammad, Op. Cit., h. 82.

6 Jurdi, Fajlurrahman. (2006). Teori Negara Hukum, Malang: Setara Press, h.72.
} 
lainnya yang hendak memberikan gagasan susunan Pancasila. Para bapak bangsa ini juga mengaminkan konsepsi negara hukum (rechtsstaat) di dalam penyelenggaraan negara. Konsep negara hukum ini berdasarkan referensi masa kolonialisme yang berdasar pada sistem Eropa Kontinental. ${ }^{7}$

Kaitannya dengan hukum yang berlaku bagi negara Indonesia dasar ideologi Pancasila telah diakui sebagai dasar negara dan dimasukan dalam penjelasan umum di UUD 1945 yang asli. Pancasila sebagai rechtsidee atau cita hukum yang menjadi dasar negara. ${ }^{8}$ Cita hukum dan konsep tentang hukum (rechtsbegriff) itu beda, konsep tentang hukum itu menyangkut kehidupan berdasarkan nilai dan norma yang telah ditentukan di dalam konstitusi atau wertbezogene. Sedangkan cita hukum (rechtssidee) merupakan ide, gagasan, dan pikiran, yang definisinya lebih dekat kepada pemaknaan Pancasila dengan tujuan mengabdi kepada nilai-nilai yang diinginkan di masyarakat. ${ }^{9}$ Begitu pula dengan keinginan masyarakat atas dasar konstitusi mengenai kemaritiman, yang hingga masa reformasi sudah terjadi belum ada juga blue constitution yang clear.

Dalam suatu pembentukan negara yang haruslah terpenuhi unsur-unsur berdirinya suatu negara. Unsur-unsur negara ialah territorial, rakyat, dan kekuasaan. ${ }^{10}$ Inti dari negara ialah menguasai suatu wilayah dan diakui secara internasional. Suatu negara dibilang eksis apabila menempati suatu wilayah yang menjadi haknya guna kepentingan kesatuan sosial dan kesatuan geografis. ${ }^{11}$ Territorial suat wilayah tidak melulu mengenai daratan, namun juga beberapa negara seperti Indonesia, Kanada, dan Cina memiliki wilayah laut dengan persentasi lebih besar atau sama dari keberadaan wilayah daratannya. Hal ini membuktikan bahwa Hans Kelsen membuka wacana berpikir territorial negara mencakup wilayah daratan dan lautan. Hal inilah yang dikatakan sebagai wilayah terpadu secara horizontal. Ada pula kondisi suatu negara wilayah teritorialnya dipisahkan dengan wilayah territorial negara lain. Wilayah daratan yang terpisah secara geografis dapat menjadi suatu kesatuan yang terhimpun dalam tatanan hukum ialah dengan menjadi wilayah penghubung laut menjadi bagian kekuasaan wilayah tertiorial suatu negara.

Tatanan hukum dijalankan sebagaimana ketetntuan hukum positif yang berlaku pada suatu negara dengan memberikan kejelasan mengenai batas-batas wilayah negara tertentu. Pembatasan kekuasaan negara atas suatu wilayah yaitu dengan memberikan kejelasan keberlakuan hukum positif di negaranya dengan ketentuan hukum international maupun hukum luar negeri (foreign law). Keterbatasan lingkup dalam menjalankan tatanan hukum pada suatu wilayah yang dikuasai negara (territorial) memiliki unsur yang bersifat memaksa, dan terdapat sanksi apabila melanggarnya. Hukum yang ditetapkan suatu negara termasuk di dalamnya konstitusi negara, mengenai sifat keberlakuannya hanya hingga batas territorial suatu negara tersebut. Maka dari itu, wilayah territorial pun hendaknya memiliki dasar konstitusi sebagai acuan yang kuat bagi negara untuk menjaga kemanan dan ketahanan negara sebagai bagian dari tatanan hukum.

7 Ibid., hal. 72-73., Lihat juga Aidul Fitriciadia, Pancasila dan Arsitektur Negara Hukum Indonesia: Upaya Dekolonialisasi dan Rekonstruksi Tradisi, Prosiding Konferensi dan Dialog Nasional Negara Hukum, dengan tema: Negara Hukum Indonesia Kemana akan Melangkah? (Jakarta: 9-10 Oktober 2012), h. 92 .

8 Ibid.

9 Attamimi, A. Hamid S. (1992). Pancasila Cita Hukum dalam Kehidupan Hukum Bangsa Indonesia, dalam Pancasila sebagai Ideologi dalam Berbagai Bidang Kehidupan Bermasyarakat, Berbangsa, dan Bernegara, Jakarta: BP 7 Pusat, h. 67.

10 Kelsen, Hans. (2016). Teori Umum Hukum dan Negara, Terjemahan Raisul Muttaqien, (Bandung: Nusa Media, h. 297.

11 Ibid., Lihat juga W.W. Willoughby, Fundamental Concept of Public Law, h. 64. 
Keberlakuan suatu tatanan hukum nasional diberlakukan dalam suatu ruang lingkup wilayah dengan cara tindakan paksa yang dilakukan oleh negara sebagai amanah daripada hukum positif negara tersebut. Sedangkan negara lain tidak memiliki wewenang untuk menjalankan tatanan hukumnya di wilayah suatu negara yang terpisah berdasarkan wilayah teritorialnya. Hal ini menjelaskan bahwa adanya kedaulatan negara atas wilayah yang dikuasainya. Namun jarang sekali negara-negara di dunia menuliskan secara eksplisit keberadaan wilayah mana saja yang menjadi bagian dari negara tertentu. Berdasarkan hal ini juga yang dicetuskan oleh Prof. Jimly Asshiddiqie sebagai isu dari negara hukum berdasarkan blue constitution, melalui sambutan pada Dies Natalis Fakultas Hukum Universitas Indonesia 2017. Dikarenakan negara yang memiliki hamparan wilayah laut terbesar di dunia itu ada pada Indonesia, namun Indonesia tidak memiliki konstitusi yang mengatur secara jelas wilayah perairannya di dalam UUD 1945. Indonesia hanya mengemalkan ketetentuan Pasal 33 UUD 1945, dengan meratifikasi UNCLOS 1982.

Negara Kesatuan Republik Indonesia (NKRI), sebagai salah satu subjek hukum internasional yang merdeka pada 17 Agustus 1945 sudah diakui keberadaannya oleh dunia internasional, yaitu Mesir, India, dan Arab Saudi. Berdasarkan yang tercantum pada Alinea Keempat UUD 1945 mengenai tujuan dibentuknya negara Indonesia. ${ }^{12}$ Indonesia merupakan suatu negara kepulauan dan menjadi inisiator terbentuknya United Nations Convention on the Law of the Sea (UNCLOS) tahun 1982. Indonesia memiliki laut yang luas yaitu lebih kurang 5,6 juta $\mathrm{km}^{2}$ dengan garis pantai sepanjang $81.000 \mathrm{~km}$, dengan berbagai potensi sumber daya, terutama perikanan laut yang cukup besar pasca berlakunya UNCLOS 1982. Indonesia memiliki wilayah perairan laut yang sangat luas namum kurang terjaga sehingga mudah mendatangkan ancaman sengketa batas wilayah dengan negara tetangga. Landas kontinen negara Republik Indonesia berhak atas segala kekayaan alam yang terdapat di laut sampai dengan kedalaman 2.500 meter. ${ }^{13}$ Batas laut teritorial sejauh 12 mil dari garis dasar lurus dan perbatasan zona ekonomi eksklusif (ZEE) sejauh 200 mil dari garis dasar laut.

Hal tersebut tidak terlepas dari semakin meningkatnya aktivitas pelayaran di wilayah perairan Indonesia, khususnya di laut teritorial. Peningkatan intensitas pelayaran sebagian di antaranya kapal barang dan penangkap ikan, tidak menutup kemungkinan terjadinya kecelakaan laut. Selain itu, Indonesia masih banyak mengalami sengketa perbatasan dengan negara tetangga. Kurangnya pengawasan terhadap laut di wilayah Indonesia telah banyak menyebabkan hilangnya kekayaan alam yang terkandung di dalamnya terutama potensi perikanan yang banyak dicuri nelayan asing. ${ }^{14}$ Perlunya pemahaman mengenai laut, sehingga pengelolaan dan pengawasan terhadap laut benarbenar harus berjalan optimal.

Berkaitan dengan gambaran umum di atas perlulah diketahui mengenai dasar pengetahuan dari laut teritorial atau perairan teritorial (territorial sea) yaitu, suatu wilayah kedaulatan negara pantai dikategorikan sebagai wilayah selain daratan dan perairan pedalaman. ${ }^{15}$ Bagi suatu negara kepulauan seperti Indonesia, laut teritorial

12 Pembukaan UUD 1945 Alinea Keempat, memuat mengenai fungsi dan tujuan Negara Indonesia, susunan Negara Republik Indonesia, Sistem Pemerintahan dan Pancasila.

13 Parthiana, I Wayan. (2015). Landas Kontinen Dalam Hukum Laut Internasional, Bandung: Mandar Maju, h. 28.

${ }^{14}$ Widodo, Reza Irfa. TNI AL Akui Kurang Optimal dalam Pengawasan Keamanan Laut, 2016, http://www.nasional.republika.co.id/berita tertanggal 25 April 2016, diakses pada tanggal 03 November 2018 pukul 17.31 WIB.

15 Prijanto, Heru. (2007). Hukum Laut Internasional, Malang: Bayumedia, h. 8. 
meliputi pula suatu jalur laut yang berbatasan dengannya. Perairan kepulauannya dinamakan laut internal atau laut dalam termasuk dalam istilah laut territorial, sementara pengertian kedaulatan ini meliputi ruang udara di atas laut teritorial serta dasar laut dan tanah di bawahnya. ${ }^{16}$ Kedaulatan atas laut teritorial dilaksanakan dengan menurut ketentuan Konvensi Perserikatan Bangsa-Bangsa tentang Hukum Laut atau yang sering disebut dengan UNCLOS 1982, lebar perairan pesisir ini dapat diperpanjang paling banyak dua belas mil laut (22.224 km) dari garis dasar (baseline-sea). ${ }^{17}$

Latar belakang penunjang dasar penelitian ini berhubungan pula dengan istilah zona ekonomi eksklusif yang didefinisikan sebagai wilayah laut di luar laut teritorial, di mana negara-negara pantai memiliki kedaulatan atas semua sumber daya alam di dalamnya dan memiliki hak terhadap penerapan yurisdiksi negara Pantai. Zona ini berada pada 200 mil dari garis pangkal laut teritorial. Sekiranya lebar laut teritorial 12 mil, maka sebenarnya lebar zona ekonomi eksklusif adalah 200 mil dikurangkan 12 mil, sehingga diperoleh hasil 188 mil untuk lebar zona ekonomi eksklusif suatu negara. ${ }^{18}$

Masih berkaitan dengan gambaran umum di atas, dasar hukum wilayah perbatasan perairan di Indonesia belum ditetapkan secara eksplisit dengan undang-undang, kecuali untuk batas sebagian Selat Singapura, yaitu dengan Undang-undang Nomor 7 Tahun 1973 dan Selat Malaka dengan Undang-undang Nomor 2 Tahun 1971. Berdasarkan UNCLOS 1982 dan Peraturan Pemerintah Nomor 38 Tahun 2002 tentang daftar koordinat garis pangkal kepulauan secara umum mengatur mengenai batas laut teritorial Indonesia dapat ditarik 12 mil laut dari garis pangkal kepulauan Indonesia. Titik koordinat dasar garis pangkal kepulauan telah diatur di dalam ketentuan Peraturan Pemerintah Nomor 38 Tahun 2002. Secara khusus ada bagian-bagian di wilayah perairan Indonesia yang memiliki pengecualian yang berkenaan dengan perbatasan wilayah perairan dengan negara tetangga, seperti halnya antara negara Indonesia dan negara Singapura batas laut teritorial di sebelah barat dan timur bagian Selat Singapura yang lebarnya kurang dari 24 mil laut, sehingga diperlukan adanya perundingan bersama antara Indonesia, Singapura, dan Malaysia. ${ }^{19}$

Wilayah laut suatu negara yang terkandung di dalam ketentuan UUD 1945 disebut oleh Jimly Asshiddiqie sebagai blue constitution. Hal ini dilemparkan ke publik untuk membuka wacana berfikir mengenai kedaulatan maritim Indonesia sebaga negara kepulauan dengan wilayah laut terbesar di dunia. Sudah semestinya segala tindak tanduk penyelenggaraan negara berbasis kemaritiman sebagai fokusnya. Di dalam kemaritiman tidak hanya mengatur wilayah saja, namun ada juga hak ekonomi kelautan di dalamnya. ${ }^{20}$ Wilayah kemaritiman pun meliputi kondisi pertahanan dan keamanan negara Indonesia berdasarkan UUD 1945 Pasca amandemen. Kemaritiman tidak hanya menyangkut keutuhan suatu wilayah akan tetapi terkait juga pada kondisi ketertiban dan aspek lain menyangkut ancaman dari negara lain yang berbatasan dengan wilayah Indonesia. Beberapa kali Indonesia kecolongan terdapat pencurian ikan di wilayah perairan pulau Natuna Indonesia. Keamanan nasional sebagai amanah daripada UUD 1945 mutlak sebagai hak inklusif organ-organ negara dalam hal partisipasi publik berkaitan penentuan

16 Pasal 33 ayat 3 UUD 1945, bumi, air, dan kekayaan yang terkandung di dalamnya dikuasai oleh negara dan dipergunakan untuk sebesar-besarnya kemakmuran rakyat.

17 Prijanto, Heru Op. Cit., h. 9.

18 Ibid., hal. 11.

19 Lihat Lampiran Peraturan Pemerintah Nomor 38 Tahun 2002 tentang Daftar Koordinat Geografis Titik-Titik Garis Pangkal Kepulauan Indonesia.

${ }^{20}$ Sambutan Jimly Asshiddiqie dalam Dies Natalis FH UI 2017. 


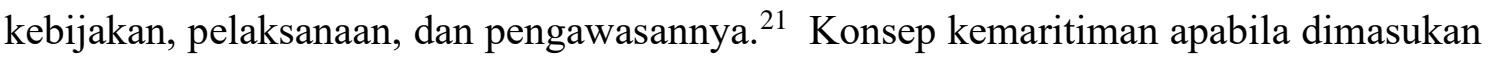
ke dalam konstitusi secara jelas dan clear, maka akan menciptakan hal yang paling esensial yaitu kesejahteraan dan kemakmuran masyarakat (prosperity).

Proses perubahan sosial dan kenegaraan dalam masa reformasi saat ini, perlu dijaga dengan baik. Apabila tidak dijaga, maka akan menimbulkan ancaman bagi ketahanan suatu dan keamanan bagi suatu negara. Haruslah terdapatpula perubahan pada UUD 1945 yang bersifat kemaritiman (blue constitution) untuk menjelaskan secara detail dan menjadi kecenderungan penyelenggaraan negara yang bersifat pro pada kemartiman di Indonesia. Karena sudah bertahun-tahun tidak ada kejelasan pada konstitusi dan kurang fokusnya pemerintah untuk mengawal dan menjaga wilayah perairan baik dari sisi keamanan maupun ekonomi masyarakat yang bergantung kepadanya. Semua organ yang menyangkut penegakan hukum di wilayah maritime Indonesia hanya didasarkan pada peraturan perundang-undangan mengenai laut Indonesia. Bukan menjadi fokus utama negara dalam hal mengelola negara berbasis maritim. Bahkan di dunia pun belum ada yang dapat dicontoh penyelenggaraan negara berbasis blue constitution.

Ketika membandingkan dengan negara lain mengenai keamanan suatu negara yang menciptakan kesejahteraan, seperti di negara Amerika dalam preambulenya menjelaskan, yaitu: ${ }^{22}$

"We the people of United States, in order to form a more perfect union, establish justice, insure domestic Transquillity, provide for the common defence, promote the general Welfare, and secure the Blessing of Liberty to ourselves and our Posterity, do ordain and establish this Constitution for the United States of America”.

Sedangkan dalam pembukaan Konstitusi Perancis menyatakan seperti juga di negara Amerika dalam preambulenya menjelaskan, yaitu: ${ }^{23}$

"The French people hereby solemnly proclaim their dedication to the Rights of Man and the Principles of national sovereignity as defined by the Declaration of 1789, reaffirmed and complemented by the Preamble to the 1946 Constitution

By virtue of these principles and that of the determination of peoples, the Republic offers to Overseas Territories expressly desiring this to adhere to them bew institutions based on the common ideal of liberty, equality, and fraternity and conceived with view to their democratic evolution".

Mengapa saya mengaitkannya pada negara hukum ialah jika kita embaca ketentuan UUD 1945 yang asli baik bagian Pembukaan maupun bagian batang tubuh, maka tidak ada satu perkataan atau kalimat yang menyatakan bahwa Indonesia merupakan negara hukum, kemudian atas dasar itulah dilakukan juga Amandemen Ketiga atas Pasal 1 ayat 3 UUD 1945, yang menyatakan bahwa negara Indonesia merupakan negara hukum. Hal ini sebenarnya pernah terjadi sebelumnya pada saat penerapan Pembukaan Konstitusi RIS yang menyatakan bahwa untuk mewujudkan kebahagiaan, kesejahteraan, perdamaian, dan kemerdekaan dalam masyarakat dan negara hukum Indonesia merdeka yang

21 Sukma, Rizal Reformasi Sektor Keamanan Indonesia: Pengertian, Tujuan, dan Agenda, dalam Marpaung, Rusdi dkk. (eds), (2005). Dinamika Reformasi Sektor Keamanan, Jakarta: Imparsial, h. 19.

22 Thomson, Brian. (1993). Textbook on Constitutional \& Administrative Law, Third Edition, London: Blackstone Press Limited, h. 13-15.

23 Asshiddiqie, Jimly. (2008). Menuju Negara Hukum yang Demokratis, Jakarta: Sekretariat Jenderal dan Kepaniteraan Mahkamah Konstitusi, h. 82-82. 
berdaulat sempurna. ${ }^{24}$ Kemudian di Pasal 1 ayat 1 Konstitusi RIS menentukan Republik Indonesia Serikat yang merdea dan berdaulat ialah suatu negara hukum yang demokrasi dan berbentuk federasi. Hal tersebut sudah di amandemen dan intisarinya di masukan dalam UUD 1945 yang sudah di amandemen.

Negara hukum yang sudah dituliskan dalam UUD 1945 dalam perjalanannya yang asli, di bagian penjelasan umum tentang sistem pemerintahan negara, pada pokok pikiran I dijelaskan bahwa negara Indonesia adalah berdasar atas hukum (rechtsstaat) tidak berdasar atas kekuasaan (machtsstaat) ${ }^{25}$ Menurut Joeniarto, ada tulisan negara hukum dalam konstitusi bukan berarti jaminan apakah negara tersebut merupakan negara hukum. Untuk menentukan suatu negara tersebut negara hukum atau bukan, dilihat dari implementasi atau praktek atas prinsip-prinsip pada negara hukum yang diakui, ditaati, dan dilaksanakan. ${ }^{26}$ Bahwa pada hakikatnya negara hukum yaitu, segala bentuk penyelenggaraan didasari atas hukum, bahkan unsur-unsur dari negara hukum pada sistem Eropa Kontinental ialah supermasi hukum, penghormatan atas hak asasi manusia, pelaksanaan berdasarkan undang-undang, dan adanya peradilan administrasi. ${ }^{27}$

Fungsi hukum dalam negara hukum ialah termasuk hal yang pokok bagi masyarakat seperti wilayah perairan di Indonesia. Keadilan dalam hal hadirnya negara hukum dalam wilayah kemaritiman diciptakan untuk hubungan-hubungan yang saling berkesinambungan antara masyarakat satu dengan lainnya, tanpa adanya gangguan dari pihak ketiga yang tidak berkepintingan seperti negara lain. Untuk itu perlu adanya normanorma (ugeren) yang dapat dijadikan ukuran tentang keadilan tersebut. ${ }^{28}$ Karena meskipun pada prakteknya lembaga-lembaga negara maupun stakeholder bergerak untuk menjaga dan memanfaat-kan wilayah perairan Indonesia, namun tanpa adanya norma di konstitusi mengenai kemaritiman, negara tidak memfokuskan diri, dan Indonesia akan selalu memfokus-kan diri pada bidang lain yang kurang relevan. Sedangkan potensi maritim ini sangatlah besar, dan apabila Indonesia dapat mencantumkan konstitusi maritim dalam UUD 1945, dapat menjadikan Indonesia sebagai negara the fourth super state in the world.

Disamping norma mengenai hubungan tersebut, di satu sisi perlu juga adanya kewenangan dalam hal kemaritim-an, sehingga tidak adanya tumpang tindih dalam penyelenggaraan organ negara di wilayah perairan Indonesia. ${ }^{29}$ Segala hal yang disampaikan, pada intinya ialah fungsi negara yang berdasarkan hukum, menegakan kebenaran untuk mencapai keadilan, pembentuk hukum di dalam menentukan hukum hendaklah mem-pertimbangkan rasa hukum yang ada pada masyarakat, terlebih lagi di negara demokratis segala bentuk pembentukan hukum wajib melibatkan lembaga perwakilan atau wakil rakyat dalam menentukan di setiap klausul mengenai perubahan UUD 1945 tentang konstitusi maritim. Para anggota pembentuk hukum harus memiliki pengetahuan tentang rasa hukum laut yang benar, dan berciri khas Indonesia, serta sifatnya bottom up dari masyarakat. Kesadaraan dan ketaatan bagi negara maupun masyarakat merupakan syarat mutlak untuk terciptanya keadilan. ${ }^{30}$

24 Joeniarto, (1968). Negara Hukum, Yogyakarta: Badan Penerbit Gadjah Mada, h. 1.

25 Ibid., h. 2. Lihat juga Penjeleasan UUD 1945 (asli), Bagian Umum Tentang Sistim Pemerintahan Negara, Pokok Pikiran I.

${ }^{26}$ Ibid.

27 Ibid., h. 3 .

28 Ibid., h. 3.

${ }^{29}$ Ibid.

30 Ibid., h. 7-9. Negara hukum pada pokoknya mengenai kebebasan hak-hak dasar bagi masyarakat untuk terhindar dari kesewenang-wenangan negara, dalam hal ini menyangkut wilayah maritim. 


\section{Konsepsi blue constitution dalam Demokrasi di Indonesia}

\section{a. Historis Demokrasi}

Awal mula masyarakat politik terbentuk dalam masa sejarah Indonesia ialah secara alami, dengan menciptakan kebebasan, kedudukan yang sama, dan independen. ${ }^{31}$ Satusatunya cara untuk melepaskan kehendak bagi kebebasan masyarakat yaitu dengan melakukan perikatan dengan masyarakat lainnya (bonds of civil society) demi terciptanya kedamaian, kenyamanan, dan keamanan di tengah masyarakat yang lebih besar ukurannya. Berkaitan dengan kehidupan demokrasi di Indonesia, sesuai dengan Arend Lijphart bahwa demokrasi tidak hanya berurusan mengenai pemerintahan berdasarkan rakyat, namun juga di masa Abraham Lincoln formula dari demokrasi itu ditujukan bagi kepentingan rakyat secara luas. ${ }^{32}$ Ideal dari sistem demokrasi ialah suatu tindakan nyata yang selalu berdasarkan kesepakatan yang berasal dari seluruh kehendak masyarakat. ${ }^{33}$

Sedemikian urgennya untuk mendefinisikan demokrasi yang nanti dapat ditarik benang merah dengan kedaulatan rakyat yang dimiliki oleh Indonesia, sejak konstitusi dirumuskan oleh para founding fathers. Karena dari pemaknaan definisi dapat merasionalisasikan setiap ke-pemimpinan yang memaknai kedaulatan rakyat dengan interpretasinya masing-masing. Interpretasi pelaksanaan kedau-latan rakyat dari yang bersifat kolektivitas hingga individualitas. Adanya definisi demokrasi sebagai kehendak masyarakat luas, dengan demikian akan terhindar dari penyalahgunaan kekuasaan (abuse of power). Sebagai konsekuensi daripada perlindungan hak asasi manusia saat mengamalkan konsep demokrasi tersebut. ${ }^{34}$

Robert A Dahl mengungkapkan alasan kenapa demokrasi tetap eksis dan responsive apabila sedikitnya ada delapan hal yang menunjang demokrasi sebagai berikut: ${ }^{35}$

a) Freedom to form and join organization, kebebasan untuk membentuk dan ikut dalam perkumpulan;

b) Freedom of expression, kebebasan untuk berekspresi;

c) The right to vote, hak untuk memilih;

d) Eligibility for public office, kelayakan untuk mengisi jabatan publik;

e) The right of political leaders to complete for support and votes, hak untuk ikut serta dalam konstestasi politik untuk mendukung dan didukung;

f) Alternative sources of information, sumber alternative informasi;

g) Free and fair elections, pemilihan bebas dan adil;

h) Institution for making government policies depend on votes and other expressions of preference, institusi pemerintahan menyangkut kebijakan publik berdasarkan pada pemilihan umum dan pilihan lainnya.

Kekuasaan tertinggi dalam suatu negara ialah kedaulatan. Jack $\mathrm{N}$ Hagel mengunkapkan ada dua hal terpenting ialah lingkup kekuasaan (scope of power) dan

31 Arinanto, Satya. (2018). Politik Hukum 1, (Jakarta: Pascasarjana Fakultas Hukum Universitas Indonesia, h. 3. Lihat John Locke, The Second Treatise of Government, (New York: Bobbs Merrill).

${ }^{32}$ Lihat Arend Lijphart, Democracies: Patterns of Majoritarian and Consensus Government in Twenty-One Century, New Haven and London: Yale University Press.

33 Arinanto, Satya $O p$ Cit., h. 25. Di dalam Lijphart, Arend .Democracies: Patterns of Majoritarian and Consensus Government in Twenty-One Century, New Haven and London: Yale University Press.

${ }^{34}$ Lihat Arinanto, Satya. (2018). Hak Asasi Manusia dalam Transisi Politik di Indonesia. (Jakarta: Pusat Studi Hukum Tata Negara Fakultas Hukum Universitas Indonesia, h. 1. Lihat Neil J. Kritz, ed. (1995). Transitional Justice: How Emerging Democracies Reckon with Former Regimes, Volume II: Country Studies. Washington, D.C.: United States Institute of Peace Press, h. xxv.

35 Dahl, Robert A. (1971). Polyarchy: Participation and Opposition, New Haven: Yale University Press, h. 3.

$$
60 \text { |S A S I Vol. } 26 \mathrm{No} .1 \text {, Januari- Maret } 2020
$$


jangkauan kekuasaan (domain of power). ${ }^{36}$ Dua cakupan tersebut diisyaratkan pula dengan konsep daripada kolektivitas dan individualitas. Konsep kolektivitas dan individulitas digunakan sebagai parameter konsep formil dari demokrasi yang diimplemetasikan melalui praktek di kehidupan bernegara, khususnya Indonesia. Perbedaan pemaknaan dari kedaulatan rakyat dalam ranah implemetasinya didasari atas gagasan negara Indonesia. Dialektika menghasilkan ukuran bagi kekuasaan negara Indonesia, yang tercipta dari kondisi individualitas rakyat melalui klausul yang eksplisit mengenai hak-hak. Kemudian sifat individualitas rakyat dihadapkan pada kondisi kolektivitas penyelenggaraan negara. ${ }^{37}$

Bangsa Indonesia hidup dan berkembang di negeri kepulauan sepanjang khatulistiwa, suatu pontensi yang sangat strategis yang melintang di antara dua samudera besar, yaitu Samudera Hindia dan Samudera Pasifik, dan diantara dua benua yaitu benua Asia dan Benua Australia. Di samping itu bangsa Indonesia memiliki kekayaan alam yang beraneka ragam, baik di darat maupun di laut. Maka letak dan bentuk geografis Indonesia serta kekayaan alamnya yang melimpah, telah membuat posisi Indonesia sangat unik di dunia internasional, khususnya di bidang hukum laut. ${ }^{38}$

Setiap negara, bagaimanapun sederhana tingkat pertumbuhannya, senantiasa memiliki seperangkat kaidah yang mengatur susunan organisasi negara yang terdiri dari organ-organ atau jabatan-jabatan kenegaraan. Perangkat kaidah semacam inilah yang dinamakan konstitusi. Dalam pengertian ini, tidaklah ada dan tidak pernah ada negara tanpa konstitusi. Namun demikian, tidaklah pula ada negara-negara yang memiliki konstitusi yang persis sama. Satu sama lain ada perbedaannya. Perbedaan-perbedaan terjadi karena latar belakang yang berbeda, seperti sejarah, budaya, ideologi, falsafah dan sebagainya. ${ }^{39}$

Sama halnya dengan wacana dan peristilahan terhadap green constitution tidak dapat disangkal memang merupakan fenomena baru, bahkan para sarjana hukum tata negara sendiri rata-rata belum pernah mendengar adanya istilah green constitution itu. ${ }^{40}$ Pertanyaan mendasar terhadap konsep green constitution apakah berasal dari pemikiran dalam negeri atau pengaruh dari dunia luar. Namun satu hal yang menjadi penting bahwa kebutuhan masyarakat akan lingkungan yang sehat menjadi sebuah keniscayaan dari hak asasi manusia yang termuat di dalam UUD Tahun 1945. Ide menempatkan pengaturan hak asasi terhadap lingkungan dalam konstitusi Negara sebagai komitmen terhadap perlindungan dan pengelolaan lingkungan hidup. Untuk itu green Constitution menjadi salah satu hal yang menjawab berbagai macam kekhawatiran masyarakat berkenaan dengan penurunan fungsi lingkungan. Selanjutnya berkaitan dengan ide kemaritiman yang berkaitan dengan kehidupan masyarakat banyak tentu sudah saatnya mendapatkan

36 Budiardjo, Miriam. (1986). Aneka Pemikiran tentan Kuasa dan Wibawa, Jakarta: Sinar Harapan, h. 14. Lihat Hagel, Jack. (1975). "Scope and Domain of Power" ini, The Descriptive Analysis of Power, New Haven: Yale University, 1975, h. 14.

37 Asshiddiqie, Jimly. (1994). Gagasan Kedaulatan Rakyat dalam Konstitusi dan Pelaksanaannya di Indonesia, Jakarta: Ichtiar Baru Van Hoeve, h. 12-13.

38 Yusuf, Chandra Motik. (2010). Negara Kepulauan Menuju Negara Maritim, dalam kegiatan 75 Tahun Prof. Dr. Hasjim Djalal, MA . Jakarta: Ind Hill.Co, 2010, h. 1.

39 Manan, Bagir. (1995). Pertumbuhan dan Perkembangan Konstitusi Suatu Negara, Bandung: Mandar Maju, h. 1.

40 Permasalahan lingkungan tidak hanya lagi menjadi tanggungjawab satu negara saja, namun menjadi tanggungjawab semua Negara dalam mewujudkan environmental sustainable. Isu global warming dan greenhouse effect turut serta menjadi salah satu factor pembicaraan hangat terhadap kondisi lingkungan di dunia. Seperti yang disampaikan oleh Jimly Asshiddiqie pada Dies Natalis Fakultas Hukum UI 2017. 
tempat yang sama di dalam UUD $1945 .^{41}$

Di zaman modern sekarang, hukum konstitusi cenderung berkembang makin universal, karena di dalamnya terdapat nilai-nilai yang dipinjam atau diadopsi dari pengalaman sukses, baik mengenai pemikiran maupun praktik kenegaraan di negaranegara lain di dunia. Universalitas nilai-nilai konstitusi ini melanda seluruh dunia, meskipun tidak mengabaikan aspek-aspek kultural dan sejarah khas yang terdapat dalam konstitusi setiap Negara. ${ }^{42}$ Hal inilah yang membuktikan bahwa sebuah konstitusi itu memiliki sifat flexible atau dapat berubah seiring dengan perkembangan lingkungan maupun zaman. ${ }^{43}$ Hal senada dapat dilihat dari pendapat David A. Strauss yang menyebutkan bahwa do we have a living constitution? Do we want to have a living constitution? A "living constitution" is one that evolves, changes over time, and adapts to new circumstances, without being formally amended. ${ }^{44}$

Pertimbangan keputusan beberapa pengembalian stabilitas demokrasi untuk perlindungan dari kejahatan persekusi pemerintahan dengan pendekatan militer. ${ }^{45} \mathrm{Hal}$ tersebut mencederai konsep kedaulatan rakyat yang telah diatur dalam Undang-Undang Dasar 1945. Persekusi oleh militer merupakan perbuatan yang salam dalam sistem otokrasi. Beberapa pejabat yang melakukan kejahatan tersebut akan mengalami peradilan kejahatan genoside dirinya dimasa yang akan mendatang saat demokrasi baru tercipta.

Kebebasan dalam demokrasi terkadang menetapkan secara natural keinginan dan kapasitas. Pemerintahan biasanya meyakinkan masyarakat dengan kekuatan dan sumber daya yang memadai untuk menghadapi permasalahan dalam demokrasi secara serius. ${ }^{46}$ Berkaca pada pendapat Dankwart Rustow, bahwa intensitas namun secara jelas tidak dapat dimenangkan dengan struggle, merupakan hal yang esensial untuk transisi dalam demokrasi di Indonesia. ${ }^{47}$

Sesungguhnya masa Orde baru berhubungan dengan orde lama sebelum-nya yakni pemerintahan Orde Lama atau Orde Demokrasi Terpimpin yang diawali pada targgal 5 Juli 1959 pada saat Presiden Soekamo mengumumkan dekrit Presiden, untuk kembali ke Undang-Undang Dasar 1945. Pada waktu itu tidak ada pihak yang menyatakan tidak setuju akan hal itu. Padahal sesungguhnya pada waktu itu Bung Kamo berstatus sebagai presiden yang hanya mempunyai ke-kuasaan sebagai kepala negara. Sebagai kepala negara secara teoritis tidak mempunyai kekuasaan politik. ${ }^{48}$

Termasuk di dalamnya menyatakan untuk kembali kepada Undang-Undangan Dasar 1945 melalui Dekrit Presiden. Semestinya pemyataan untuk kembali ke UndangUndang Dasar 1945 dinyatakan oleh Perdana Menteri Djuanda, sebagai kepala

41 Asshiddiqie, Jimly. (2010). Green Constitution, Jakarta: Rajawali Press, h. 1.

42 Ibid., h. 2.

43 Priyanta, Maret. (2010). Penerapan Konsep Konstitusi Hijau (Green Constitution) di Indonesia Sebagai Tanggung jawab Negara Dalam Perlindungan dan Pengelolaan Lingkungan Hidup, Jurnal Konstitusi, Volume 7, Nomor 4, Jakarta: Agustus 2010, h. 116.

44 Strauss, David A. (2010). The Living Constitution, New York: Oxford University Press, h. 1.

45 Linz, Juan J. (1982). The Transition from the Authoritarian Regimes to Democratic Political Systems and the Problems of Consolidation of Political Democracy, Unpublish Manuscript, Tokyo: IPSA Tokyo Roundtable, 29 Maret-1 April.

46 Arinanto, Satya Politik Hukum I, Op Cit., h. 201.

47 Ibid., h. 202. Lihat Rustow, Dankwart. (1970). Transitions to Democracy: Towards to a Dynamic Model, Comparitive Politics 2, h. 63.

48 Asshiddiqie, Jimly. Op Cit., h. 153. Lihat pada periode demokrasi parlementer sebelumnya sintesis antara individualisme dengan kolektivisme tidak tercapai. Ini terbukti dengan menonjolnya praktek liberalisme dalam perkembangan dan proses perpolitikan di Indonesia, situasi inilah menimbulkan Dekrit Presiden 5 Juli 1959. 
pemerintahan. Secara konstitusional pun, di dalam Undang-Undang Dasar Sementara tahun 1950 (UUDS '50) yang menjadi dasar negara pada waktu itu, dalam Pasal 134 UUDS 1950 menyatakan bahwa "Konstituante (sidang pembuat Undang-Undang Dasar bersama-sama dengan pemerintah selekas-lekasnya menetapkan Undang-undang Dasar Republik Indonesia yang akan menggantikan Undang-undang Dasar Sementara. Dalam UUDS '50 tidak ada ketentuan yang menyatakan bahwa berlakunya sebuah UndangUndang Dasar 1945 menyatakan oleh presiden. Disamping itu Bung Kamo sebagai presiden dapat dinilai telah dengan sungguh-sungguh melanggar. ${ }^{49}$

Pada masa itu adanya pembatasan bagi rakyat yang hendak berserikat, pembatasannya dengan membungkan segala aspirasi diluar ideologi NASAKOM dengan mekanisme pengambul per-mufakatan yang dikendalikan secara ketat dan terpimpin. Hal tersebut diatur di dalam TAP MPRS No. VIII/MPRS/1965. Kemudian pada tahun 1968 terdapat TAP No. XXXVII/MPRS/ 1968 yang mencabut TAP MPRS No. VIII/MPRS/1968 berdasarkan pada konsiderannya.

Sesungguhnya pada saat terjadi pergantian Rezim, yang kini dikenal dengan Rezim Orde Lama ke Orde Baru merupakan kesempatan untuk melakukan pembaruan Hukum sekaligus langkah koreksi dan reformasi setelah pada masa lalu banyak terjadi penyimpangan terhadap konstitusi. Untuk memulihkan tatanan negara yang berlandaskan pada Undang-Undang Dasar 1945 dan Pancasila. Namun, patut disayangkan, pada masa Orde Baru hukum justru dimanfaatkan oleh penguasa sebagai legitimasi segala tindakan untuk mengamankan "kebijakan" yang diambil pada masa itu. Selama 32 tahun Orde Baru mengamankan roda pemerintahan, demokrasi mandeg. Pemusatan kekuasaan terjadi. Negara sepenuhnya berada di tangan seorang presiden. Hal ini bisa terjadi karena perangkat hukum yang ada dimanfaatkan untuk memberi legitimasi ke arah terpusatnya kekuasaan pada presiden. Hal mi tercermin pada paket undang-undang politik yang berakibat demokrasi terkamuflase dalam setiap aktivitas berbangsa dan bernegara. ${ }^{50}$

Konstitusi, telah dimanfaatkan untuk mengesahkan tindakan kenegaraan yang pada dasamya justru anti demokrasi, pembatasan partai politik, pemberangusan pers, tersumbatnya keseluruan komunikasi, adalah sejumlah fakta yang sangat mudah ditemukan pada masa ini. Selanjutnya Orde Baru dalam upaya memberlakukan UUD secara mumi dan konsekwen, dalam pembentukan Undang-undang belum mencerminkan demokrasi, sebab lembaga penyusun undang-undang, yakni DPR dan presiden belum bisa "berdiri sama tinggi duduk sama rendah". 51

Demokrasi yang dipraktekan masih terbatas pada level demokrasi formal, yakni dilakukan oleh DPR sebagai wakil rakyat, namun masih banyak komponen rakyat yang secara materil belum tertampung di DPR. Menurut Phillipe Nonet dan Selznick bahwa bangunan dari suatu negara yang melakukan pendekatan yang totaliter pastilah sangat erat kaitannya dengan hukum represif yang menekankan pada sifat memaksa dalam sisi peraturan dan kekuasaannya. ${ }^{52}$ Bangsa dan rakyat negeri harus ingat bahwa pada awal Orde Baru berdiri bangunan untuk menuju masa depan harus dirancang, pilihan utamanya pada pembangunan sektor ekonomi. Dengan menitikberatkan pada sisi maka, waktu itu ada dua pilihan yakni pemerataan atau pertumbuhan. Dan pilihan jatuh pada Pertumbuhan. Karena pilihan pada pertumbuhan maka, harus didukung oleh situasi politik, yang stabil.

49 Ibid., h. 154.

50 Asshiddiqie, Jimly $O p$ Cit., h. 172.

51 Ibid.

52 Satya, Arinanto, Politik Hukum 2, (Jakarta: Pascasarjana Universitas Indonesia, 2018), hal. 80. Lihat Phillipe Nonet dan Phillipe Selznick, Law and Society in Transition: Toward Responsive Law. 
Artinya stabilitas nasional menjadi sesuatu hal yang harus dibangun lebih dulu. Secara demikian maka, muncul doktrin bahwa apa yang dikatakan pemerintah adalah sesuatu yang benar. Karena harus dianggap benar maka dalam proses penyusunan Undangundang harus tidak bertele-tele. ${ }^{53}$

Harus dibangun adanya pihak yang lebih berkuasa daripada pihak yang lain. Oleh karenanya harus ada lembaga yang terbelenggu dalam menyusun undang-undang, Jadilah DPR yang gagap dalam menyuarakan hati nurani rakyat, bahkan munculnya 5 paket Undang-undang politik (UU Pemilu, 'UU Kedudukan dan Susunan MPR/ DPRI/DPRD UU Parpol, UU Ormas dan UU Refferendum, yang menjadi salah satu agenda demo mahasiswa kini sedang marak untuk mencabut lima paket itu,) menjadi DPR semakin ompong. Situasi itulah yang mengantarkan belum terciptanya undang-undang secara demokratis.

Disamping hal tersebut di atas konstitusi Indonesia, yakni Undang-Undang Dasar 1945 sebelum diamandemen memberi peluang yang lebih dominan membuat UU adalah presiden sesuai ketentuan Pasal 5 Undang-Undang Dasar 1945 bahwa: 'presiden memegang kekuasaan tertinggi undang-undang", sedang DPR hanya diberi hak mengajukan rancangan UU (lihat Pasal 21 UUD 1945). Kondisi seperti tersebut di atas lebih diperparah dengan DPR yang tidak mencerminkan struktur masyarakatnya. Sebab secara sosiologis, masyarakat menghendaki adanya partai politik baru, sebagai altematif partai yang ada. Namun karena sudah ditentukan oleh undang-undang hanya ada dua partai politik dan Golongan Karya, maka sebesar apa pun keinginan masyarakat untuk mendirikan partai politik selalu terganjal oleh aturan yang ada. Temyata situasi yang berkembang semakin mengarah bahwa terciptanya UU dilakukan tidak secara demokratis, bahkan cenderung ditentukan oleh presiden yang pada akhimya menjurus pada pemusatan kekuasaan. Jika pemusatan kekuasaan terjadi berarti tidak ada jaminan bagi masyarakat, sebab pemerintah mempunyai kebebasan sangat besar. ${ }^{54}$

Pada perkembangan saat ini sangatlah diperlukan keberadaan konstitusi maritime bagi negara Indonesia, karena Indonesia merupakan negara kepulauan terbesar di dunia. Sudah sepantasnya kita sebagai negara yang besar memiliki dasar konstitusi mengenai maritim. Maritim yang dimaksud tidak melulu mengenai batas wilayah, namun juga mengenai hak ekonomi kelautan bagi masyarakat Indonesia yang hendak melakukan pekerjaannya sebagai nelayan. Beberapa tahun ke belakang ini Indonesia selalu dirugikan mengenai pencurian ikan di wilayah perairannya. Kasus besar yang dihighlight dalam tugas ini ialah, overlappingnya wilayah perairan Indonesia dengan negara-negara tetangga seperti Singapura, Malaysia, Filipina, dan Laut Cina Selatan. Pada kesempatan ini, penulis menghubungkan kedudukan negara demokrasi mengenai hak-hak ekonomi kelautan masyarakat Indonesia yang dilanggar. Sudah beberapa kali mengganti pimpinan, namun tidak ada satu pun yang melakukan pembentukan konstitusi maritim.

\section{b. Blue Constitution}

Perubahan konstitusi sesuai dengan perubahan zaman tentunya menjadi sebuah keharusan dalam mengimbangi perubahan-perubahan yang terjadi di dalam masyarakat kita. Perubahan dalam memasukkan wacana yang berkembang ke dalam sebuah konstitusi akan mendorong kemajuan bagi sebuah Negara. David A. Strauss menyatakan

53 Wignjosoebroto, Soetandyo. (2014). Dari Hukum Kolonial ke Hukum Nasional, Jakarta: Huma, Van Vollen Hoven Institute, KITLV Jakarta, dan Epistema Institute, h. 209.

54 Arinanto, Satya Politik Hukum 2, Op Cit., h. 77. Lihat Nonet and Helznick, If we taken as given the urgencies of leadership then the most perspective source of the repressionis what Meriam called the proverty of power. And there is nothing suprising to the holders of power or perhaps to its subjects. 
so it seems inevitable that the constitution will change, too. This is a good thing, because an unchanging constitution would fit our society very badly. Either it would be ignored or, worse, it would be a hindrance, a relic that would keep us from making progress and prevent our society from working in the way it should. ${ }^{55}$

Wirjono Prodjodikoro mengatakan bahwa perkataan konstitusi berarti pembentukan, berasal dari kata kerja constituer (Perancis) yang berarti membentuk. Kini yang dibentuk ialah suatu negara, maka konstitusi mengandung permulaan dari segala peraturan mengenai suatu negara. ${ }^{56}$ Ivor Jenning mengemukakan, konstitusi berfungsi mengawasi pelaksanaan pemerintahan (pengawasan konstitusional). ${ }^{57}$ James Bryce, menyatakan bahwa konstitusi berfungsi menetapkan lembaga-lembaga negara dan mengatur fungsi dan batas haknya. ${ }^{58}$ Sedangkan menurut Carl Schmit, konstitusi dianggap sebagai keputusan politik yang tertinggi. ${ }^{59}$ Oleh karena itu, konstitusi mempunyai kedudukan tertinggi dalam tertib hukum suatu negara. ${ }^{60}$ Lebih lanjut Wirjono menyebutkan bahwa konstitusi memuat peraturan-peraturan pokok (fundamental) mengenai soko guru atau sendi-sendi pertama untuk menegakkan bangunan besar yang bernama negara. Sendisendi itu tentunya harus kuat dan tidak akan mudah runtuh, agar bangunan negara tetap berdiri. ${ }^{61}$

Sedangkan pengertian konstitusi (constitution) sebagaimana dalam Webster's New Americana Dictionary diterangkan sebagai The System of Fundamental Laws of a Nation or Society (suatu sistem dari hukum-hukum dasar suatu bangsa atau masyarakat). ${ }^{62}$ Jacobeen dan Lipman dalam bukunya Political Science memberikan defenisinya sebagai a collection of norm or standars regulating the legal relations of goverments to its (sekumpulan kaidah-kaidah atau pola-pola yang mengatur hubungan legal dari pemerintah kepada warga negaranya). ${ }^{63}$ Dari pengertian konstitusi tersebut dapat penulis simpulkan bahwa konstitusi merupakan aturan dasar dan menjadi penyangga utama untuk tegak kokohnya suatu negara. ${ }^{64}$ Sedangkan menurut Titik Triwulan Tutik, berdasarkan konsepsi di atas, secara umum istilah konstitusi menggambarkan keseluruhan sistem ketatanegaraan suatu negara, yaitu berupa kumpulan peraturan yang membentuk, mengatur atau memerintah negara yang mana peraturan-peraturan tersebut ada yang tertulis dan yang tidak tertulis. ${ }^{65}$ Berkenaan dengan pengertian maritim, menurut Kamus Besar Bahasa Indonesia (KBBI) diartikan sebagai sesuatu yang berkenaan dengan laut,

55 Ibid., h. 2.

56 Wirjono Prodjodikoro, Azaz-azaz Hukum Tata negara Di Indonesia, (Jakarta: Dian Rakyat, 1983), hal. 34. Lihat juga Sobirin Malian, Gagasan Perlunya Konstitusi Baru Pengganti UUD, (Yogyakarta: UII Press, 2002), hal. 13.

57 Jenning, Ivor. (1960) The Law and the Constitution. London: University of London, h. 33.

58 Bryce, James dalam Pieris, John. (2007). Pembatasan Konstitusional Kekuasaan Presiden RI, Jakarta: Pelangi Cendekia, h. 45.

59 Ekatjahjana, Widodo. (2008). Pengujian Peraturan Perundang-undangan dan Sistem Peradilannya di Indonesia, Jakarta: Pustaka Sutra, 2008, h. 13-14. Lihat juga Mangunsong, Parlin M. (1992). Konvensi Ketata negaraan Sebagai Salah Satu Sarana Perubahan UUD, Bandung: Alumni h. 22.

60 Projodikoro, Wirjono Op. Cit.

61 Prodjodikoro, Wirjono dalam Lubis, Solly. (2008). Hukum Tata Negara, Bandung: Mandar Maju, h. 27.

62 Constitutions. (1955). Webster's New Americana Dictionary.

63 Jacobeen and Lipman, (1956). Political Science, dalam "College Outline Series ", New York: Barnes \& Nable, dikutip dalam Fadjar, Mukthie. (2005). Tipe Negara Hukum, Malang: Bayu Media, h. 79.

64 Adhayanto, Oksep. (2013). Eksistensi Hak Prerogratif Presiden Dalam Sistem Pemerintahan Presidensial Setelah Amandemen UUD 1945, Disertasi, Bandung: Universitas Islam Bandung, h. 21.

65 Tutik, Titik Triwulan. (2010). Kontruksi Hukum Tata Negara Indonesia Pasca Amandemen UUD 1945, Jakarta: Kencana, h. 87. 
berkenaan dengan pelayaran. ${ }^{66}$ Sedangkan kemaritiman diartikan sebagai hal-hal yang menyangkut masalah maritim. Selain dikenal istilah maritim juga dikenal istilah bahari. Dalam penulisan ini, penulis menggunakan istilah maritim karena dalam pandangan penulis istilah maritim mempunyai pemaknaan yang lebih luas dari istilah kelautan maupun bahari yang cendrung lebih sempit.

Jika penulis menggunakan istilah konstitusi kelautan (marine constitution) agaknya kurang tepat jika disandingkan dengan kata konstitusi yang tersirat sebagai suatu yang luas yang tidak bersifat parsial. Laut menurut Kamus Besar Bahasa Indoesia diartikan sebagai tempat berkumpulnya air (asin). ${ }^{67}$ Penggunaan kelautan menurut hemat penulis lebih cocok digunakan untuk menyebutkan aspek tertentu saja, seperti marine law. Sama halnya dengan istilah bahari yang tidak penulis gunakan sebagai pendamping dari kata konstitusi karena kata bahari lebih mendekati kepada sifat dari kebudayaan. Kata bahari dalam kamus Lengkap Bahasa Indonesia diartikan sebagai kelautan, kuno, lama sekali. ${ }^{68}$

Sedangkan dalam The Law Dictionary, laut atau sea diartikan sebagai the great mass of water which surrounds the land (massa yang besar dari air yang mengelilingi tanah) sedangkan marine menurut The Law Dictionary diartikan sebagai naval, relating or pertaining to the sea, transacted at sea, doing duty or service on the sea. Dari berbagai pengertian di atas penulis mencoba memberikan pengertian maritim dari perspektif penulis sebagai sesuatu yang berhubungan dengan laut yang dapat memberikan kemanfaatan. Maritim menurut hemat penulis jangan diartikan dalam pengertian yang sangat sempit, sebaliknya maritim dapat dilihat dari berbagai aspek seperti, sosial, hankam, hukum, sosbud, ekonomi dan lain sebagainya. Isu-isu dan wacana-wacana tentang kemaritiman memang beberapa tahun belakangan ini muncul dipermukaan sebagai salah satu alternatif dalam konsep pembangunan negara Indonesia sehingga banyak pihak berupaya untuk menggali lebih dalam sesuai dengan bidang keilmuannya.

Kemaritiman harus dipandang sebagai objek yang di dalamnya mencakup banyak bidang kehidupan yang mana antara yang satu saling terkait dengan bidang yang lainnya. Di dalam kemaritiman terdapat banyak bidang yang dapat dikembangkan seperti hukum, budaya, sosial, teknik dan tentunya perikanan dan kelautan itu sendiri. Pentingnya mendudukkan secara etimologi makna di atas agar tidak terjebak kepada distorsi pemaknaan kata sehingga menyebabkan disorientasi pemahaman. Untuk selanjutnya dalam penulisan ini penulis akan sering menggunakan istilah maritime constitution sebagai sebuah paham yang memasukkan nilai-nilai maritim di dalam sebuah konstitusi. ${ }^{69}$ Sehingga secara tersirat konstitusi maritim diartikan sebagai konstitusi yang berkaitan dengan laut yang dapat memberikan kemanfaatan. Adagium ius ubi ius society memberikan gambaran bahwa dimana ada masyarakat disitu ada hukum, pemahaman tersebut tentunya selaras dengan semangat hukum senantiasa dapat menyesuaikan diri terhadap perkembangan masyarakat. Sama halnya saat ini perkembangan kemaritiman dari berbagai aspek menuntut perkembang-an hukum yang serupa pada aspek yang sama pula. Aspek perikanan, pelayaran, ekonomi, pertam-bangan, dan lain sebagainya yang berkaitan dengan kemaritiman tentunya membutuhkan kehadiran hukum dalam rangka menciptakan ketertiban dan ketentraman.

Negara Indonesia merupakan sebuah Negara Kepulauan (Archipelago State) yang

66 Novia, Windy. (2006). Kamus Lengkap Bahasa Indonesia, Surabaya: Kashiko, h. 303.

67 Ibid., h, 286.

68 Ibid., h. 47.

69 Beding, Bona. (2013). Genealogi Laut: Dialektika Bahari Vs Maritim Eksistensi Laut Dalam Sastra Laut Lamalera, Jakarta: Makalah Diskusi Panel Serial Ketiga YSNB.

66 | S A S I Vol. 26 No.1, Januari- Maret 2020 
terdiri dari pulau-pulau kecil maupun besar serta luas wilayah laut yang lebih luas daripada luas wilayah daratan. Kondisi geografis ini tentunya akan membutuhkan berbagai bentuk kebijakan maupun peraturan perundang-undangan yang memiliki corak kemaritiman. Pengalaman Negara Indonesia \pm 69 tahun ini memberikan deskripsi bahwa dalam hal public policy maupun peraturan perundang-undangan yang dilahirkan cenderung berorientasi pada daratan (continental oriented) daripada lautan (archipelago oriented). ${ }^{70}$ Secara geografis, Indonesia sebagai Negara kepulauan yang berbasis maritim dapat dilihat dengan panjang garis pantai $95.181 \mathrm{~km}$ yang kemudian menjadikan Indonesia sebagai Negara keempat yang memiliki garis pantai terpanjang setelah Amerika Serikat, Kanada dan Rusia. Luas laut Indonesia sebesar dua pertiga dari luas Indonesia \pm $3.273 .810 \mathrm{~km}^{2}$ menjadikan Indonesia sebagai Negara kepulauan terluas didunia. ${ }^{71}$ Dilihat dari konteks kawasan regional ASEAN, Indoesia adalah Negara kepulauan terbesar yang kemudian diikuti Jepang dan Philipina.

Perjuangan Negara Indonesia dalam mendapatkan status archipelago state bukan tanpa halangan. Deklarasi Djuanda tahun 1957 menjadi catatan Indonesia mendeklarasikan sebagai negara ke-pulauan yang kemudian dibawa pada sidang United Nation Convetion Law of The Sea (UNCLOS). ${ }^{72}$ Perspektif dalam melihat laut bukan sebagai pemisah antar pulau melainkan penghubung antar pulau memberikan dampak terhadap luas Negara Indonesia pada waktu itu menjadi $5.193 .250 \mathrm{~km}^{2}$. Indonesia kemudian meratifikasi UNCLOS 1982 tersebut dengan menerbitkan Undang-Undang No. 17 Tahun 1985, sejak itu dunia internasional mengakui Indonesia sebagai Negara Kepulauan. Tentunya hal ini yang dijadikan asumsi dasar untuk melakukan penolakan terhadap konsep archipelago state bagi Negara-negara yang tidak memiliki luas laut sebagaimana Negara Indonesia. Disisi lainnya, sejarah juga mencatat bahwa Indonesia dulunya adalah Negara maritim yang kuat dengan hadirnya kerajaan Sriwijaya. ${ }^{73}$

Secara politis, klaim Negara kepulauan Indonesia tersebut dinyatakan dalam Deklarasi Djuanda pada 13 Desember 1957 yang berbunyi: ${ }^{74}$

"bahwa segala perairan, diantara dan yang menghubungkan pulau-pulau yang termasuk Negara Indonesia dengan tidak memandang luas atau lebarnya adalah bagian-bagian yang wajar daripada wilayah daratan Negara Indonesia dan dengan demikian bagian daripada perairan pedalaman atau nasional yang berada di bawah kedaulatan mutlak Negara Indonesia. Lalu, lintas yang damai di perairan pedalaman ini bagi kapal-kapal asing dijamin selama dan sekadar tidak bertentangan dengan/mengganggu kedaulatan dan keselamatan Negara Indonesia. Penentuan batas landas lautan territorial (yang lebarnya 12 mil) diukur dari garis yang menghubungkan titik-titik ujung yang terluar pada pulaupulau Indonesia. Ketentuan-ketentuan tersebut akan diatur selekas-lekasnya dengan Undang-undang”.

Deklarasi Djuanda di atas menunjukkan sikap Bangsa Indonesia terhadap penolakkan dari Territoriale Zee en Maritime Kringen Ordonantie 1939 yang tidak cocok dengan konsep negara kepulauan Indonesia. Dalam ordonantie 1939, batas territorial hanya diukur sejauh 3 mil. Deklarasi Djuanda ini kemudian melahirkan konsep wawasan

70 Koreksi PBB terhadap garis pantai Negara Indonesia Tahun 2008.

71 Ibid.

72 Adhayanto, Oksep dkk, (2009). Buku Ajar Pendidikan Kewarganegaraan, Tanjung Pinang: Umrah Press, h. 117.

${ }^{73}$ Fatwa, A. M. (2009). Potret Konstitusi pasca Amandemen UUD 1945, Jakarta: Kompas, Jakarta, h. 147.

74 Arifin, Saru. (2014). Hukum Perbatasan Darat Antarnegara, Jakarta: Sinar Grafia, h. 1-2. 
nusantara. Sebelu.m mengarah kepada peraturan perundang-undangan yang bercorak maritim, perlu kiranya dipertegas perihal wawasan maritim sebagai konsep strategis (geostrategis) yang perlu diaktualisasikan dalam konsep pembangunan. ${ }^{75}$ Sehingga keterlibatan hukum (secara umum) dalam konsep strategis tersebut sebagai alat untuk merekayasa pembangunan yang berbasis kepada kemaritiman, seperti apa yang disampaikan oleh Roscoue Pound, a tool of social enginnering. Sedangkan jika melihat dari aspek geopolitik banyak sarjana seperti Sir Walter Raleigh menyebutkan bahwa jika ingin menguasai dunia maka kuasailah lautan yang ada. Karena dengan menguasai lautan maka akan turut serta menguasai perdagangan maupun jalur perdagangan, setelah suatu Negara menguasai perdagangan maka akan menguasai kekayaan dunia dan pada akhirnya akan menguasai dunia. Berdasarkan hal ini maka muncullah konsep wawasan bahari atau konsep kekuatan laut. ${ }^{76}$

UUD 1945 sebagai konstitusi Negara Republik Indonesia memiliki banyak wajah UUD 1945 tidak saja dapat dilihat sebagai konstitusi politik (political constitution) yang mengatur pembagian kekuasaan di dalam negara, melainkan dapat pula dilihat sebagai konstitusi ekonomi (economic constitution) karena berisi dasar-dasar kebijakan Negara dibidang ekonomi. ${ }^{77}$ UUD 1945 dapat juga disebut sebagai konstitusi hijau (green constitution) karena berisi dasar-dasar pegaturan mengenai pengelolaan dan perlindungan hidup, bahkan UUD 1945 memuat pengaturan tentang konstitusi maritime (blue constitution) yang menegaskan keberadaan Indonesia sebagai Negara Kepulauan. ${ }^{78}$ Menurut pandangan Prof. Jimly Asshiddiqie pada sambutannya di Dies Natalis FH UI 2017, bahwa isu mengenai green constitution dan blue constitution harus dikembangkan. Dikarenakan Indonesia sangatlah memerlukan disamping pengembangan ilmu pengetahuan tentang ilmu ketatanegaraan, dan ilmu tentang etika. Tidak kalah penting juga pengembangan konsep green constitution dan blue constitution. ${ }^{79}$

Perubahan paradigma dan mainset terhadap pengelolaan Negara dari aspek peraturan perundang-undangan yang berbasis kepada maritim tentunya harus dimulai dari aturan yang lebih tinggi, yakni Konstitusi atau UUD 1945, sehingga aturan turunan ke bawahnya bisa merujuk kepada aturan yang lebih tinggi sebagaimana yang disampaikan dalam stuffenbau Teorinya Hans Kelsen. ${ }^{80}$ Jika dilihat dari klasifikasi sebuah konstitusi, salah satu bentuk konstitusi yang ada didunia adalah konstitusi berderajat tinggi atau konstitusi tidak berderajat tinggi (supreme constitution ant not supreme constitution). Di Indonesia sendiri jika merujuk kepada Undang-Undang No. 12 Tahun 2011 Tentang Tata Urutan Perundang-undangan maka Konstitusi Indonesia dapat dikatagorikan sebagai Supreme Constitution.

Oleh karena itulah, pentingnya UUD 1945 agar memuat ketentuan yang berkaitan dengan maritim dikarenakan UUD 1945 sebagai hukum tertinggi di Negara Indonesia dan sejalan dengan yang disampaikan oleh K.C. Wheare terhadap perlunya menempatkan konstitusi pada kedudukan yang tinggi maka terdapat semacam jaminan bahwa konstitusi itu akan diperhatikan dan ditaati dan menjamin agar konstitusi tidak akan dirusak dan diubah begitu saja secara sembarangan. Perubahannya harus dilakukan secara hikmat,

75 Adiwijoyo, Suwarno. (2005). Konsolidasi Wawasan Maritim Indonesia, PAKAR, Jakarta.

76 Adhayanto, Oksep dkk, Op. Cit., h. 119.

77 Adhayanto, Oksep. (2014). Maritime Constitution, Jurnal Selat Vol. 2 No. 1, Tanjungpinang: Fakultas Hukum Universitas Maritim Raja Ali Haji , h.

${ }^{78}$ Lihat Pasal $28 \mathrm{H}$ ayat (1) dan Pasal 33 ayat (1), (2), (3), dan (4) UUD 1945.

79 Sambutan Jimly Asshiddiqie pada kegiatan Dies Natalis FH UI 2017.

80 Kelsen, Hans. (2006). Teori Hukum Murni: Dasar-Dasar Ilmu Hukum Normatif, Bandung: Nusamedia, h. 244. 
penuh kesungguhan dan atas pertimbangan yang mendalam. Agar maksud ini dapat dilaksanakan dengan baik maka perubahannya pada umumnya mensyaratkan suatu proses dan prosedur yang khusus dan istimewa. ${ }^{81}$ Sebagai landasan konstitusional, UUD 1945 didalam pembukaan menyebutkan bahwa untuk membentuk suatu pemerintah negara Indonesia yang melindungi segenap bangsa Indonesia dan seluruh tumpah darah Indonesia dan untuk memajukan kesejahteraan umum, mencerdaskan kehidupan bangsa, dan ikut melaksanakan ketertiban dunia yang berdasarkan kemerdekaan, perdamaian abadi dan keadilan sosial, maka disusunlah kemerdekaan bangsa Indonesia itu dalam suatu UUD 1945.

Sejalan dengan itu juga, Perubahan kedua UUD 1945 sudah mempertegas bahwa Indonesia sebagai Negara Kepulauan sebagaimana tercantum didalam Pasal 25A yang menyebutkan bahwa Negara Kesatuan Republik Indonesia adalah sebuah Negara kepulauan yang berciri Nusantara dengan wilayah yang batas-batas dan hak-haknya ditetapkan dengan undang-undang. ${ }^{82}$ Adanya wilayah merupakan salah satu syarat berdirinya sebuah Negara. Dalam konstitusi-konstitusi negara-negara di dunia ini terdapat bermacam cara dalam merumuskan wilayahnya. Ada yang menggunakan garis lintang dan garis bujur, ada yang menyebutkan Negara bagiannya atau provinsinya, ada pula dengan cara menjelaskan kondisi kewilayahannya. Dalam hal ini, UUD 1945 menganut cara yang terakhir. ${ }^{83}$ Sedangkan di Malaysia dalam merumuskan wilayahnya dengan cara menyebutkan Negara bagiannya atau provinsinya sebagaimana dijelaskan pada Konstitusi Malaysia Pasal 1 angka (2), (3), dan (4).

Selanjutnya, di dalam UUD 1945 sebelum amandemen tidak terdapat penyebutan Indonesia sebagai Negara kepulauan yang bercirikan Nusantara. Oleh karena itu sangatlah wajar jika peraturan perundang-undangan dibawahnya kurang mencerminkan gagasan-gagasan tentang kemaritiman yang terdapat pada Negara Indonesia. Sesungguhnya, pada saat membahas materi rancangan perubahan UUD 1945 mengenai wilayah Negara ini, sebenarnya timbul keinginan untuk mempergunakan penyebutan Benua Maritim Indonesia untuk pengenalan wilayah Indonesia seperti yang telah dideklarasikan oleh Pemerintah Indonesia pada tahun 1957. Hal itu tidaklah berlebihan mengingat ada klaim penyebutan Benua Antartika untuk pulau Antartika yang berada di Kutub Selatan. ${ }^{84}$ Dengan adanya ketentuan mengenai wilayah negara tersebut, pada masa mendatang kemungkinan pemisahan sebuah wilayah dari NKRI makin dipersulit. Demikian pula hal itu akan mendukung penegakkan hukum di seluruh wilayah Tanah Air dalam melakukan perundingan internasional yang berkaitan dengan batas wilayah Negara Indonesia, serta pengakuan internasional terhadap kedaulatan wilayah Negara Indonesia. ${ }^{85}$

Sebagai negara berkembang, Indonesia mempunyai keinginan yang kuat untuk melaksanakan pembangunan di segala bidang, termasuk pembangunan bidang hukum guna menunjang dan mengatur pembangunan bidang lainnya seperti politik, ekonomi sosial budaya dan lain sebagainya. Pembangunan setiap aspek di Indonesia tidak selalu diikuti oleh perencanaan dan pembentukkan hukum yang menunjang dan mengatur aspek

81 Wardani, Kunthi Dyah. (2007). Impeachment Dalam Ketatanegaraan Indonesia, Yogyakarta: UII Press, h. 34.

82 Bandingkan dengan konsep green constitution yang mengusung jargon lingkungan yang terdapat dibeberapa pasal antara lain Pasal 28H, Pasal 33 ayat (4) UUD 1945.

83 A. M Fatwa, Op. Cit, h. 145.

84 Ibid., h. 147.

85 Ibid. 
tersebut. ${ }^{86}$ Salah satu aspek yang ada adalah dari aspek kemaritiman yang sampai saat ini dari segi pembangunan hukum nasional masih kurang termaksimalkan. Wacana pembangunan aspek kemaritiman yang dilihat secara luas tidak saja berkaitan dengan perikanan namun juga perekonomi-an, pertahanan dan keamanan, sosial budaya serta dari aspek hubungan internasional membutuhkan perangkat peraturan perundang-undangan yang memadai sehingga tidak menimbulkan kekosongan hukum itu sendiri. Dikarenakan konstitusi Negara Indonesia menganut bentuk fleksible, maka sangat memberikan kemudahan bagi konstitusi Indonesia untuk dapat memasukkan rumusan-rumusan yang berkaitan dengan perkembangan pada masyarakat.

Menurut Abu Bakar Busroh dan Abu Daud Busroh konstitusi pada dasarnya mengandung pokok-pokok pikiran dan paham-paham, yang melukiskan kehendak yang menjadi tujuan dari faktor-faktor kekuatan nyata (de reele Machtsfactoren) dalam masyarakat yang bersangkutan. Artinya suatu konstitusi pada dasarnya lahir dari sintesa ataupun reaksi terhadap paham-paham pikiran yang ada dalam masyarakat sebelumnya ${ }^{87}$. Selain itu juga, menurut A. A. H. Struycken, undang-undang dasar sebagai konstitusi tertulis merupakan sebuah dokumen formal yang memuat, antara lain: ${ }^{88}$

a) Hasil perjuangan politik bangsa di waktu yang lampau;

b) Tingkatan-tingkatan tertinggi per-kembangan ketatanegaraan bangsa;

c) Pandangan tokoh-tokoh bangsa yang hendak diwujudkan, baik waktu sekarang maupun untuk masa mendatang;

d) Suatu keinginan dimana perkembang-an kehidupan ketatanegaraan hendak dipimpin.

Sayangnya, gagasan-gagasan yang ada tentang kemaritiman, baru menggelora dengan kuat beberapa tahun terakhir dan mendapat perhatian khusus dari pemerintah, namun hal tersebut baru dalam tataran konsep dan wacana saja belum sampai kepada tataran implementasi. Perkembangan terhadap gagasan ke-maritiman sebenarnya sudah banyak diimplementasikan dibeberapa negara kepulauan yang ada seperti Swedia, Jepang, Philipina dan lainnya. Pemanfaatan potensi kemaritiman dari segala aspek tidak saja dari aspek perikanan membuktikan bahwa kemaritiman bukan saja perikanan namun banyak aspek lain yang dapat digali dan diberdayakan guna meningkatkan ke-sejahteraan masyarakat. Jepang begitu mahir dalam memanfaatkan potensi perikanan yang mereka miliki. Singapura sebagai negara kecil yang mampu memanfaatkan potensi maritimnya untuk perdagangan Internasional barangkali dapat dijadikan contoh yang nyata. Inggris sebagai Negara kepulauan memberikan dukungan yang besar terhadap pertahanan dan keamanan dengan menjadikan armada angkatan lautnya sebagai salah satu yang disegani di dunia. Tentunya keberhasilan Negara-negara kepulauan lainnya dalam mengembangkan kemaritiman mereka didukung oleh perangkat peraturan perundangundangan yang komprehensif dalam menggali dan memanfaatkan potensi kemaritiman itu sendiri.

Keseluruhan UUD 1945 dimana Pancasila sebagai dasar bernegara kita sebenarnya sudah bisa memaknai urgensi daripada dasar maritime di dalam konstitusi. Karena UUD 1945 yang berdsar pada Pancasila merupakan modus vivendi (kesepakatan luhur) dari seluruh para bapak bangsa untuk membentuk negara yang terciptanya kesejahteraan di

86 Goesniadhie, Kusnu. (2006). Harmonisasi Hukum dalam Perspektif Perundang-Undangan: Lex Specialis Suatu Masalah, Surabaya: JP Books, h. 1.

87 Tutik, Titik Triwulan Op. Cit., h. 88.

88 A.A.H. Struycken dalam Soemantri, Sri. (2015). Konstitusi Indonesia: Prosedur dan Sistem Perubahannya Sebelum dan Sesudah UUD 1945 Perubahan, Bandung: Rosda, h. 2. Lihat juga Suharizal dan Arifin, Firdaus. (2007). Refleksi reformasi konstitusi, 1998-2002, Bandung: Citra Aditya Bakti, h. 38. 
tengah masyarakat. ${ }^{89}$ Dari sudut hukum bahkan di dalam Pasal 33 UUD 1945 sudah menjelaskan tentang negara menguasai sumber daya alam. Apabila dasar tersebut dijelaskan secara mendetail dalam satu bab khusus di UUD 1945, maka menciptakan hukum yang berkesesuaian antara das sollen dan das sein. Pancasila sebagai sumber dari segala sumber hukum memberi solusi untuk mengatasi semua ketentuan pelaksana daripada UUD 1945, karena Pancasila adalah tempat berangkatnya sekaligus tempat tujuannya. ${ }^{90}$ Mengenai pembahasan negara hukum memang tidak terlepas daripada para sarjana seperti Montesqiue, John Lock, Machavelli, Foucault, Habermas, dan Gouw Giok Siong. Kesemuanya memberikan pemikirannya dalam hal pengembangan konsep negara hukum baik rechtsstaat atau rule of law.

Intisari dari pembentukan konstitusi kemaritiman dari sisi negara hukum maupun demokrasi ialah harus memenuhi unsur terbatas pada pembatasan kekuasaan negara terhadap perseorangan, negara tidak mahakuasa, negara tidak dapat bertindak sewenangwenang, dan tindakan negara terhadap warganya dibatasi hukum termasuk di dalamnya persoalan kemaritiman. ${ }^{91}$ Sedangkan menurut Jimly Asshiddiqie, ada beberapa prinsip pokok negara hukum salah satunya asas legalitas. ${ }^{92}$

\section{P E N U T U P}

Setelah mendalami dan mengkaji mengenai isu tentang blue constitution atau konstitusi kemartitiman dalam negara hukum dan demokrasi, maka dapat ditarik kesimpulan yaitu: Negara hukum dijalankan sebagaimana ketetntuan hukum positif yang berlaku pada suatu negara dengan memberikan kejelasan mengenai batas-batas wilayah negara tertentu. Pembatasan kekuasaan negara atas suatu wilayah yaitu dengan memberikan kejelasan keberlakuan hukum positif di negaranya dengan ketentuan hukum international maupun hukum luar negeri (foreign law). Keterbatasan lingkup dalam menjalankan tatanan hukum pada suatu wilayah yang dikuasai negara (territorial) memiliki unsur yang bersifat memaksa, dan terdapat sanksi apabila melanggarnya. Namun jarang sekali negara-negara di dunia menuliskan secara eksplisit keberadaan wilayah mana saja yang menjadi bagian dari negara tertentu. Dikarenakan negara yang memiliki hamparan wilayah laut terbesar di dunia itu ada pada Indonesia, namun Indonesia tidak memiliki konstitusi yang mengatur secara jelas wilayah perairannya di dalam UUD 1945. Indonesia hanya mengemalkan ketetentuan Pasal 33 UUD 1945, dengan meratifikasi UNCLOS 1982. Asas legalitas sebagai anasir paling utama dalam negara hukum. Tindak tanduk negara harus bersumber pada undang-undang. Bangsa Indonesia hidup dan berkembang di negeri kepulauan sepanjang khatulistiwa, suatu pontensi yang sangat strategis yang melintang di antara dua samudera besar, yaitu Samudera Hindia dan Samudera Pasifik, dan diantara dua benua yaitu benua Asia dan Benua Australia. Di samping itu bangsa Indonesia memiliki kekayaan alam yang beraneka ragam, baik di darat maupun di laut. Maka letak dan bentuk geografis Indonesia serta kekayaan alamnya yang melimpah, telah membuat posisi Indonesia sangat unik di

89 Jurdi, Fajlurrahman Op. Cit., h. 77.

90 Asshiddiqie, Jimly. (2007). Ideologi, Pancasila, dan Konstitusi, (Jakarta: Sekretariat Jenderal dan Kepaniteraan Mahkamah Konstitusi Republik Indonesia.

91 Jurdi, Fajlurrahman Op. Cit., h. 193. Lihat juga Siong, Gouw Giok. (1955). Pengertian tentang Negara Hukum, Jakarta: Keng Po, 1955. Gouw Giok Siong menyatakan bahwa asas legaliteit merupakan anasir paling utama dalam negara hukum. Tindak tanduk negara harus bersumber pada undang-undang.

92 Asshiddiqie, Jimly. (2004). Cita Negara Hukum Indonesia Kontemporer, Orasi Ilmiah, Palembang: Universitas Sriwijaya, h. 3-8. 
dunia internasional, khususnya di bidang hukum laut.

Setiap negara bagaimanapun sederhana tingkat pertumbuhannya, senantiasa memiliki seperangkat kaidah yang mengatur susunan organisasi negara yang terdiri dari organ-organ atau jabatan-jabatan kenegaraan. Perangkat kaidah semacam inilah yang dinamakan konstitusi, dalam pengertian ini, tidaklah ada dan tidak pernah ada negara tanpa konstitusi. Namun demikian, tidaklah pula ada negara-negara yang memiliki konstitusi yang persis sama. Satu sama lain ada perbedaannya. Perbedaan-perbedaan terjadi karena latar belakang yang berbeda, seperti sejarah, budaya, ideologi, falsafah dan sebagainya. Satu hal yang menjadi penting bahwa kebutuhan masyarakat akan lingkungan yang sehat menjadi sebuah keniscayaan dari hak asasi manusia yang termuat di dalam UUD Tahun 1945. Berkaitan dengan ide kemaritiman yang berkaitan dengan kehidupan masyarakat banyak tentu sudah saatnya mendapatkan tempat yang sama di dalam UUD 1945. Di zaman modern sekarang, hukum konstitusi cenderung berkembang makin universal, karena di dalamnya terdapat nilai-nilai yang dipinjam atau diadopsi dari pengalaman sukses, baik mengenai pemikiran maupun praktik kenegaraan di negaranegara lain di dunia. Universalitas nilai-nilai konstitusi ini melanda seluruh dunia, meskipun tidak mengabaikan aspek-aspek kultural dan sejarah khas yang terdapat dalam konstitusi setiap Negara. Hal inilah yang membuktikan bahwa sebuah konstitusi itu memiliki sifat flexible atau dapat berubah seiring dengan perkembangan lingkungan maupun zaman. Hal senada dapat dilihat dari pendapat David A. Strauss yang menyebutkan bahwa do we have a living constitution? Do we want to have a living constitution? A "living constitution" is one that evolves, changes over time, and adapts to new circumstances, without being formally amended.

\section{DAFTAR PUSTAKA}

\section{Buku}

[1] Adhayanto, Oksep, dkk. (2009) Buku Ajar Pendidikan Kewarganegaraan. Tanjungpinang: Umrah Press.

[2] Adiwijoyo, Suwarno. (2005). Konsolidasi Wawasan Maritim Indonesia. Jakarta: Pakar.

[3] Arifin, Saru. (2014). Hukum Perbatasan Darat Antarnegara. Jakarta: Sinar Grafia.

[4] Arinanto, Satya. (2018). Politik Hukum 1. Jakarta: Pascasarjana Fakultas Hukum Universitas Indonesia.

[5] Arinanto, Satya. (2018) Politik Hukum 2. Jakarta: Pascasarjana Universitas Indonesia..

[6] Arinanto, Satya. (2018). Hak Asasi Manusia dalam Transisi Politik di Indonesia. Jakarta: Pusat Studi Hukum Tata Negara Fakultas Hukum Universitas Indonesia.

[7] Asshiddiqie, Jimly. (1994). Gagasan Kedaulatan Rakyat dalam Konstitusi dan Pelaksanaannya di Indonesia. Jakarta: Ichtiar Baru Van Hoeve.

[8] Asshiddiqie, Jimly. (2007). Ideologi, Pancasila, dan Konstitusi. Jakarta: Sekretariat Jenderal dan Kepaniteraan Mahkamah Konstitusi Republik Indonesia.

[9] Asshiddiqie, Jimly. (2008). Menuju Negara Hukum yang Demokratis. Jakarta: Sekretariat Jenderal dan Kepaniteraan Mahkamah Konstitusi.

[10] Asshiddiqie, Jimly. (2010). Green Constitution. Jakarta: Rajawali Press.

[11] Attamimi, A. Hamid S. (1992). Pancasila Cita Hukum dalam Kehidupan Hukum Bangsa Indonesia, dalam Pancasila sebagai Ideologi dalam Berbagai Bidang Kehidupan Bermasyarakat, Berbangsa, dan Bernegara. Jakarta: BP 7 Pusat.

[12] Budiardjo, Miriam. (1986). Aneka Pemikiran tentan Kuasa dan Wibawa. Jakarta: 
Sinar Harapan.

[13] Dahl, Robert A. (1971). Polyarchy: Participation and Opposition. New Haven: Yale University Press.

[14] Ekatjahjana, Widodo. (2008). Pengujian Peraturan Perundang-undangan dan Sistem Peradilannya di Indonesia. Jakarta: Pustaka Sutra.

[15] Fadjar, Mukthie. (2005). Tipe Negara Hukum. Malang: Bayu Media.

[16] Fatwa, A. M. (2009). Potret Konstitusi pasca Amandemen UUD 1945. Jakarta: Kompas.

[17] Goesniadhie, Kusnu. (2006). Harmonisasi Hukum dalam Perspektif PerundangUndangan: Lex Specialis Suatu Masalah. Surabaya: JP Books.

[18] Hagel, Jack. (1975). The Descriptive Analysis of Power. New Haven: Yale University.

[19] Jacobeen and Lipman, (1956). Political Science, dalam "College Outline Series". New York: Barnes \& Nable.

[20] Jenning, Ivor. (1960). The Law and the Constitution. London: University of London.

[21] Joeniarto, (1968). Negara Hukum. Yogyakarta: Badan Penerbit Gadjah Mada.

[22] Jurdi, Fajlurrahman. Teori Negara Hukum. Malang: Setara Press. 2016.

[23] Kelsen, Hans. (2006). Teori Hukum Murni: Dasar-Dasar Ilmu Hukum Normatif. Bandung: Nusamedia.

[24] Kelsen, Hans. (2016). Teori Umum Hukum dan Negara. Terjemahan Raisul Muttaqien. Bandung: Nusa Media.

[25] Kritz, Neil J. ed. (1995). Transitional Justice: How Emerging Democracies Reckon with Former Regimes, Volume II: Country Studies. Washington, D.C.: United States Institute of Peace Press.

[26] Lijphart, Arend. (1984). Democracies: Patterns of Majoritarian and Consensus Government in Twenty-One Century. New Haven and London: Yale University Press.

[27] Locke, John. (1956). The Second Treatise of Government. New York: Bobbs Merrill.

[28] Lubis, Solly. (2008). Hukum Tata Negara. Bandung: Mandar Maju.

[29] Malian, Sobirin. (2002). Gagasan Perlunya Konstitusi Baru Pengganti UUD 1945. Yogyakarta: UII Press.

[30] Manan, Bagir. (1995). Pertumbuhan dan Perkembangan Konstitusi Suatu Negara. Bandung: Mandar Maju.

[31] Mangunsong, Parlin M. (1992). Konvensi Ketata negaraan Sebagai Salah Satu Sarana Perubahan Undang-Undang Dasar. Bandung: Alumni.

[32] Nonet, Phillipe dan Phillipe Selznick. (1978). Law and Society in Transition: Toward Responsive Law. New York: Harper \& Row.

[33] Novia, Windy. (2006). Kamus Lengkap Bahasa Indonesia. Surabaya: Kashiko.

[34] Parthiana, I Wayan. (2015). Landas Kontinen Dalam Hukum Laut Internasional. Bandung: Mandar Maju.

[35] Pieris, John. (2007). Pembatasan Konstitusional Kekuasaan Presiden RI. Jakarta: Pelangi Cendekia.

[36] Prijanto, Heru. (2007). Hukum Laut Internasional. Malang: Bayumedia.

[37] Prodjodikoro, Wirjono. (1983). Azaz-azaz Hukum Tata negara Di Indonesia. Jakarta: Dian Rakyat.

[38] Rustow, Dankwart. (1970). Transitions to Democracy: Towards to a Dynamic Model, Comparitive Politics 2.

[39] Siong, Gouw Giok. (1955). Pengertian tentang Negara Hukum. Jakarta: Keng Po.

[40] Soemantri, Sri. (2015). Konstitusi Indonesia: Prosedur dan Sistem Perubahannya Sebelum dan Sesudah UUD 1945 Perubahan. Bandung: Rosda.

[41] Strauss, David A. (2010). The Living Constitution. New York: Oxford University Press. 
[42] Suharizal, dan Arifin, Firdaus. (2007). Refleksi reformasi konstitusi, 1998-2002. Bandung: Citra Aditya Bakti.

[43] Sukma, Rizal. (2005). Reformasi Sektor Keamanan Indonesia: Pengertian, Tujuan, dan Agenda, dalam Rusdi Marpaung dkk. (eds). Dinamika Reformasi Sektor Keamanan. Jakarta: Imparsial.

[44] Thomson, Brian. (1993). Textbook on Constitutional \& Administrative Law. Third Edition. London: Blackstone Press Limited.

[45] Tutik, Titik Triwulan. (2010). Kontruksi Hukum Tata Negara Indonesia Pasca Amandemen UUD 1945. Jakarta: Kencana.

[46] Wardani, Kunthi Dyah. (2007). Impeachment Dalam Ketatanegaraan Indonesia. Yogyakarta: UII Press.

[47] Wignjosoebroto, Soetandyo. (2014). Dari Hukum Kolonial ke Hukum Nasional. Jakarta: Huma, Van Vollen Hoven Institute, KITLV Jakarta, dan Epistema Institute. 2014.

[48] Willoughby, W.W. Fundamental. Concept of Public Law.

[49] Yusuf, Chandra Motik. (2010). Negara Kepulauan Menuju Negara Maritim, dalam kegiatan 75 Tahun Prof. Dr. Hasjim Djalal, MA. Jakarta: Ind Hill.Co.

\section{Jurnal dan Lain-Lain}

[50] Adhayanto, Oksep. (2013). Eksistensi Hak Prerogratif Presiden Dalam Sistem Pemerintahan Presidensial Setelah Amandemen UUD 1945. Disertasi. Bandung: Universitas Islam Bandung.

[51] Adhayanto, Oksep. (2014). Maritime Constitution. Jurnal Selat Vol. 2 No. 1. Tanjungpinang: Fakultas Hukum Universitas Maritim Raja Ali Haji.

[52] Asshiddiqie, Jimly. (2004). Cita Negara Hukum Indonesia Kontemporer. Orasi Ilmiah. Palembang: Universitas Sriwijaya.

[53] Beding, Bona. (2013). Genealogi Laut: Dialektika Bahari Vs Maritim Eksistensi Laut Dalam Sastra Laut Lamalera. Jakarta: Makalah Diskusi Panel Serial Ketiga YSNB.

[54] Fitriciadia, Aidul. (2012). Pancasila dan Arsitektur Negara Hukum Indonesia: Upaya Dekolonialisasi dan Rekonstruksi Tradisi. Prosiding Konferensi dan Dialog Nasional Negara Hukum, dengan tema: Negara Hukum Indonesia Kemana akan Melangkah? Jakarta..

[55] Linz, Juan J. (1982). The Transition from the Authoritarian Regimes to Democratic Political Systems and the Problems of Consolidation of Political Democracy, Unpublish Manuscript, Tokyo: IPSA Tokyo Roundtable.

[56] Priyanta, Maret. (2010). Penerapan Konsep Konstitusi Hijau (Green Constitution) di Indonesia Sebagai Tanggung jawab Negara Dalam Perlindungan dan Pengelolaan Lingkungan Hidup. Jurnal Konstitusi. Volume 7, Nomor 4. Jakarta.

[57] Widodo, Reza Irfa. (2016). TNI AL Akui Kurang Optimal dalam Pengawasan Keamanan Laut, 2016. http://www.nasional.republika.co.id 